\title{
Offshore Electric Ship Charging Station: a Techno-Economic Analysis
}

\author{
Cawas Phiroze Nazir ${ }^{1}$ \\ (Received: 10 September 2021 / Revised: 20 December 2021 / Accepted: 21 December 2021)
}

\begin{abstract}
GHG). This paper proposes the feasibility of implementing grid-like batteries- onboard ocean-going vessels along with an offshore electric charging station (OECS) to offer fully electric sailing across longer distances. The (OECS) is proposed to be built in deep waters along commercial shipping routes. Such an installation has a floating solar plant, in conjunction with a battery energy storage system to meet the charging demands of an all-electric ship (AES). The technology was evaluated based on a case study of an AES cargo vessel traveling between Mumbai and Dubai with a one-stop midway (at an OECS) for recharging batteries. When compared to a diesel ship, the AES showed savings of 5,627,293liters of diesel/yr and a reduction of 19,823 tonnes of $\mathrm{CO}_{2}$. The study shows that the integration of an OECS along with the AES concept is feasible, and represents a major milestone in bringing emission-free technology to the marine sector.
\end{abstract}

Keywords - Offshore charging station, photovoltaic generation, tension leg platform, electric sailing, battery storage, emissions.

\section{INTRODUCTION}

A worldwide diesel emission from ships is responsible for almost $2.5 \%$ of total greenhouse gases (GHG) according to IMO 2009 [1]. It produces 1 million tons of $\mathrm{CO} 2$ each year. This makes it the fourthbiggest sector in emissions globally, Micco, et al. [2]. Although this percentage is relatively low for the volume of cargo transported, shipping is responsible for a greater percentage share of NOx $(\sim 15 \%)$ and SOx $(\sim 4.9 \%)$, Eyring ET, al[3]. A 2007 estimation revealed that CO2 emissions from 45,620 vessels amounted to 943 million tons, with the total fuel oil consumption being 297 million tons International Chamber of Shipping, [4]. Marine shipping forms the bulk of global trade. Approximately $80 \%$ of world trade by volume is carried by sea, UNCTAD, [5]. New technologies need to be explored to mitigate greenhouse gases (GHG), without impacting the marine trade. This requires that power generation and power propulsion plants for future ships have to significantly reduce fuel consumption and emission. Recently, photovoltaic (PV) energy to reduce their greenhouse gas emissions and improve energy efficiency has been tried. However, excessive use of solar energy is found to increase investment cost and the uncertainty associated with solar power, making the power system unstable, Balcombe, et al. [6]. To overcome this drawback, a wide range of investigations, Zakeri \& Syryri [7] have found that the use of an energy storage system (ESS) is an effective solution for ensuring the reliability and power quality of power systems and favors the increased penetration of distributed generation resources. This has led to the development of AllElectric Ships (AES), having an integrated power system consisting of renewable sources and battery energy storage systems (BESS), Sakalis et, al [8]. A typical example of a ship with electric propulsion is HNLMS Rotterdam. Diab et, al[9] has shown that for a ship stand-

Cawas Phiroze Nazir is Independent Consulting Engineer, Kolkata, India. E-mail: cpnazir@gmail.com alone power system, the NPC of hybrid PV/diesel/ESS power generation is less than that of PV/diesel power generation. Sectors such as energy production, storage, and motor vehicles, have realized the advantages of green technologies and renewable energy sources and this has led to their being used extensively, European Commission [10]. More recently, Nazir [11] has explored the possibility of using solar photovoltaic (PV) with battery energy storage systems for high-speed rail transportation.

Notwithstanding the advantages of modern vessels with electric propulsion, batteries are still not efficient enough and are too heavy to be considered as options for ships that make long-distance trips. Hence, they are reduced to traveling short distances requiring frequent charging. A typical application is a battery-powered ferry MF Ampere. The ferry's crossing which goes between Oppedal and Lavik, near Bergen, Norway, takes about 30 minutes, Corvus Energy [12]. The vessel is powered by $1.04 \mathrm{MWh}$ Li-ion batteries, recharged by two 410 $\mathrm{kWh}$ charging stations. In another example, a fully electric container ship has been sailing on the Pearl River in southern China. It can travel a distance of $80 \mathrm{~km}$, and the 1000 li-ion batteries achieve 2,400 kWh, Quanlin [13].

The majority of shipping involves deep-sea vessels that have big travel ranges. These vessels require enormous amounts of energy to operate Koumentakos A.G. [14], and so far, there have been no technologies to fulfill the requirements of a fully electric ship. To take full advantage of that battery-powered AES provide, and to move away from the limitations of shore-based charging along coastal routes, a novel concept is presented, wherein the world's first zero-emission offshore electric charging station (OECS) is proposed to be built in deep waters along commercial shipping routes. This would permit large ocean-going vessels with big battery installations to recharge their batteries and increase their range of travel. This concept has been made possible by the rapid advances in battery technology, power electronics, the practical applications of floating solar plants, and the successful implementation of deep-water floating foundation 
structural systems, aspects which have been covered in subsequent chapters.

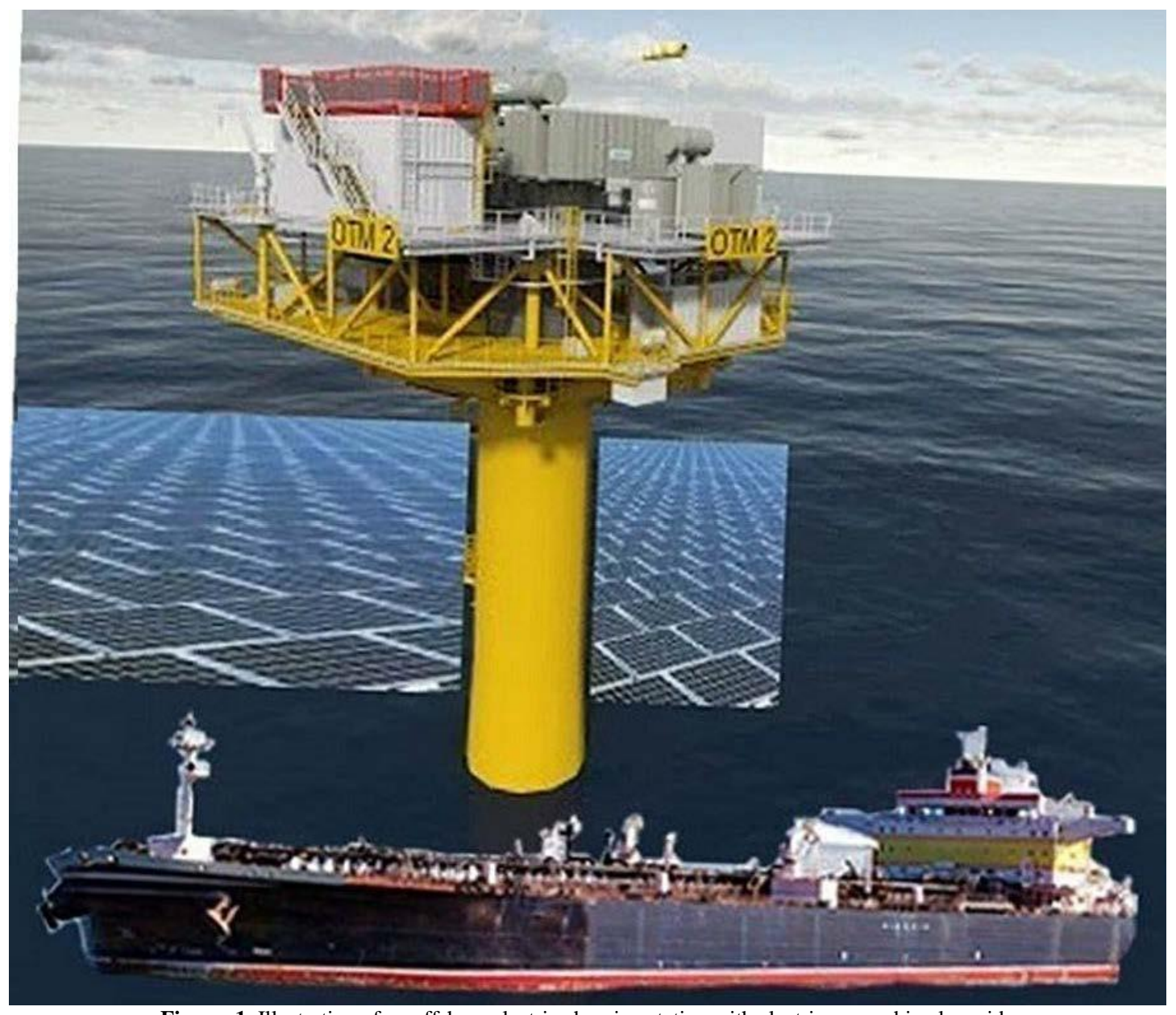

Figure. 1. Illustration of an offshore electric charging station with electric cargo ship alongside

The OECS is at the heart of this technology. Whereas many land-based electric charging stations have been installed, mainly for routes catering to ferry operations, Corvus Energy [12], installing an OECS at sea poses a formidable challenge. To begin with, the OECS has to have a more robust design to cope with the marine environment. Commercial technologies are now available, which offer promising solutions. Ocean Sun and Swimsol are two such companies SERI [15]. To support the batteries, an artificial platform has to be installed at depths over $200 \mathrm{~m}$ below sea level. Such platforms were developed for the oil and gas industry with the Tension Leg Platform being the preferred choice for depths up to $1500 \mathrm{~m}$, Sadeghi et, al [16]. Finally, to store the energy from the PV plant, a battery with high energy density, with reduced weight and size consideration was required. TESLA MegaPack [17], requiring $40 \%$ less space than its counterparts offered the ideal solution. A similar battery pack was also considered for the AES.

AES and hybrid ships with battery storage can now recharge their batteries at this station, allowing the possibility of fully electric sailing across greater travel distances, and over a longer period. These vessels will also require charging stations in ports, and the harbor area grid must be designed to accommodate the charging of batteries for hybrid and electric vessels.

This paper presents a method for optimally sizing a hybrid PV/BESS offshore electric charging station for charging batteries on an AES navigating a typical route between Mumbai and Dubai. Specifically, this work proposes an approach to generating power from PV arrays on a floating solar plant (FSP) and then charging batteries (BESS) on a co-located OECS. An illustration of the OECS design used for battery charging of electric ships is shown alongside an AES cargo ship, Figure I.

The design, construction, installation, and costs for an OECS are presented. Comparative case studies of an AES based on PV/BESS power generation are made with a conventional diesel dry cargo vessel of 10,000 dwt, traveling between Mumbai and Dubai (approx distance $1941 \mathrm{~km}$ ); with one-stop mid-way (at OECS) for recharging batteries. The results of costs and energy produced by the PV/BESS are given. NPC, fuel consumption, and emission for the AES are compared with a conventional diesel ship of similar capacity. These show the great advantages that such a scheme could provide. With $100 \%$ renewable electricity generation, powering zero-emission ocean-going all-electric ships, the concept presents a major milestone in bringing emission-free technology to the marine sector. 


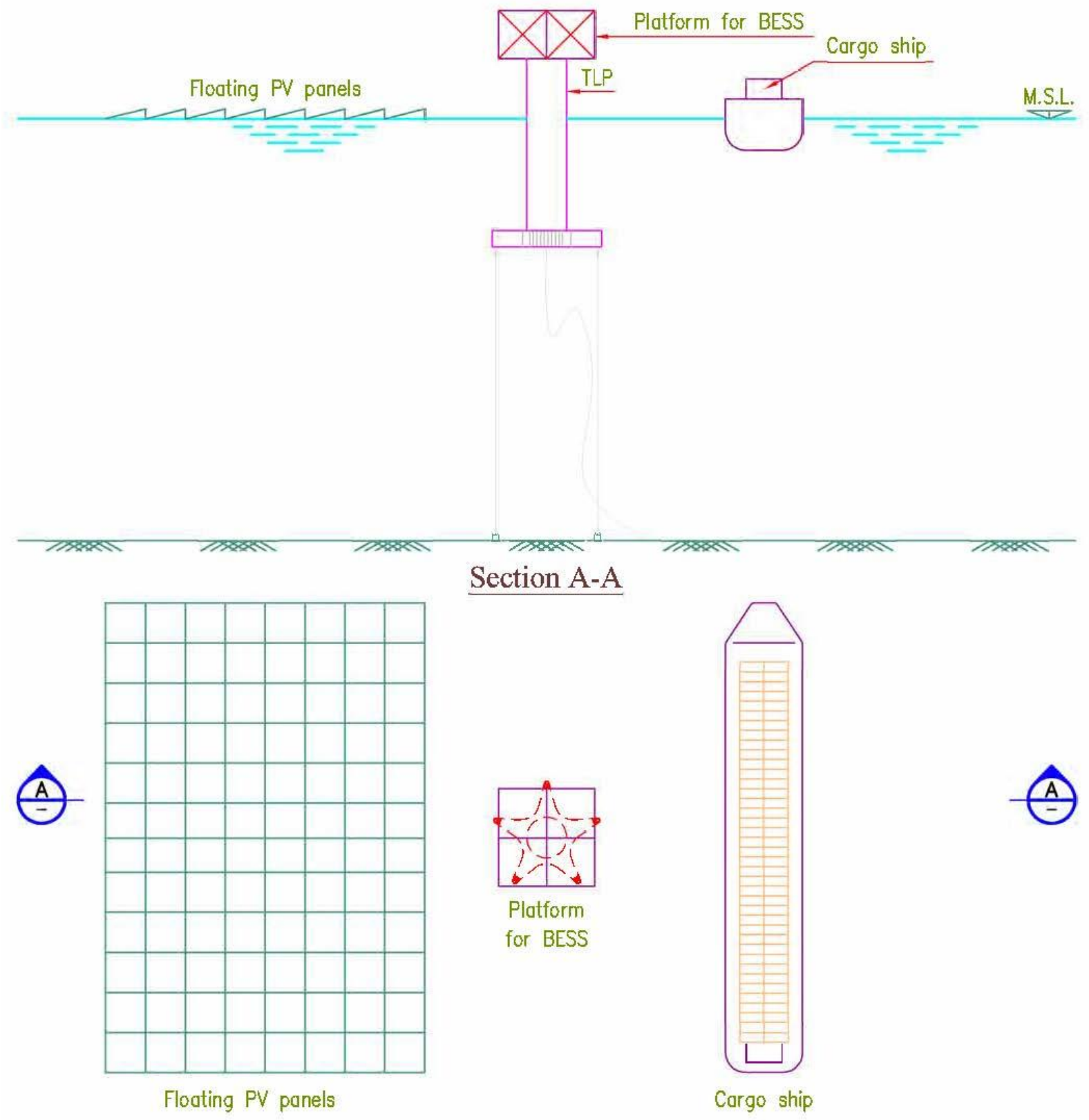

Figure. 2. Schematic plan \& section of OECS with cargo ship alongside

The design under consideration is evaluated from a techno-economic point of view utilizing HOMER Pro software, version $3.13 .7 \quad[18]$ and specifically considering the net present cost (NPC) as a metric to compare the various design options. The subsequent sections of the paper are structured as follows: Section 2 provides a methodology of the proposed technology and gives an overview of to design of the main components. Section 3presents studies for the computational analysis by way of an example of a practical design application of an AES with recharging at OECS and the obtained results for the case studies are extensively discussed. Section 4 ends with conclusions.

\section{METHOD}

This research aims to prove the viability of the first zero-emission technology for an electric ship charging platform OECS in marine lanes and combine it with AES towards a carbon-free world. TheOECS could provide a source for recharging batteries of modern AES and hybrid ships so that they could sail across longer distances and over a longer period. Such a design would lead to a major reduction in (GHG)and help the shipping industry to reduce its environmental impact. This has been made possible by the rapid advances in battery technology, power electronics, the practical applications of floating solar plants, and the successful implementation of deepwater floating foundation structural systems. In the present study PV, solar panels mounted on pontoons would harvest the energy from the sun and provide the energy required to charge BESS colocated on OECS. 


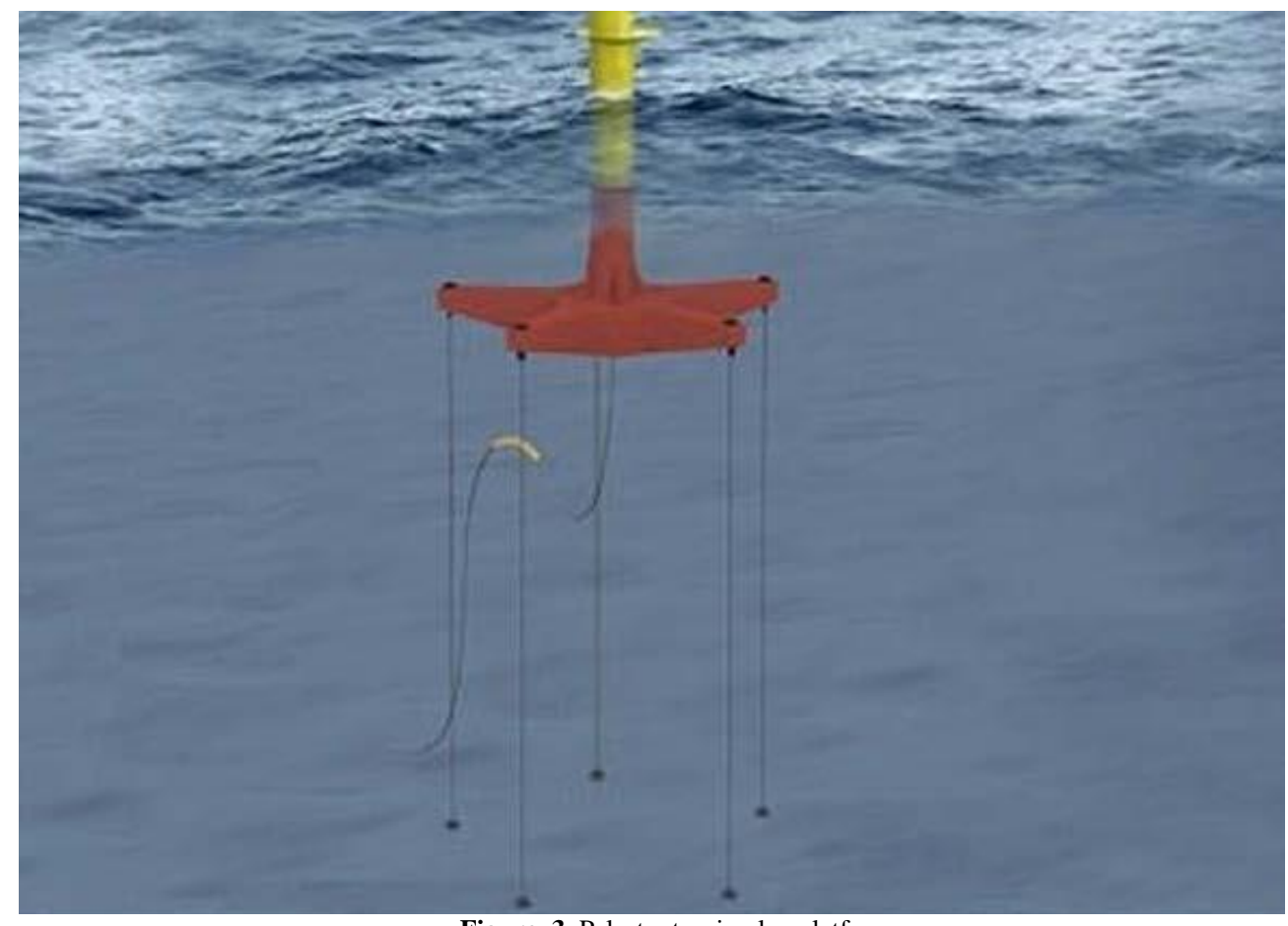

Figure. 3. Pelastar tension leg platform

In a novel comparison of Hybrid Renewable Energy Systems (HRES) on land and on ships, Diab et, al [9] have shown that increasing the use of PV systems on ships significantly decreases the fuel consumption and the total greenhouse gas (GHG) emissions. In another study, Lan et al. [19] has demonstrated that the net present value of hybrid PV/diesel/ESS power generation is less than that of $\mathrm{PV} /$ diesel power generation. The batteries located in BESS are charged during sunlight hours. They are intended to be sized similar to the ones installed on the AES such, that the ship can use battery power for main propulsion during its entire travel period. BESS, sub-station, control room, and charging device are mounted on a Tension Leg Platform (TLP). A new or reengineered AES would dock alongside the TLP and the batteries will be re-charged from BESS either manually or by an automated shore power connection. The OECS could also be used to charge the batteries on a hybrid ship. At ports, the batteries on AES will be charged from the local grid. A typical layout of the new design is shown in Fig.2.

\section{A. All-Electric Ship}

Strict environmental norms introduced by the International Convention for the Prevention of Pollution from Ships, MARPOL Treaty [20] have encouraged the development and adoption of various clean energy technologies. Solar power has been used to a limited extent to power ships. Because of the small energy density that PV provides, solar power alone is not able to fully power ships. This has led to ships being developed with hybrid propulsion having two or more power sources. The power source could be a) combustion power supply from diesel engines and b) stored power supply from energy storage systems. The economic benefits of an electric propulsion system with hybrid power have been investigated by Volker [21]. In such a case, this would allow vessels to acquire significantly bigger engine capacity and greater travel distances. China launched the first such electric cargo ship Quanlin, [13]. It has a battery capacity of $2.4 \mathrm{MWh}$ which enables it to cover a distance of $80 \mathrm{~km}$ on a single charge. Typically, an AES has no internal combustion engine onboard; and its main source for propulsion is battery power. In assessing the technical feasibility, the weight and volume of BESS are critical factors as they affect the ship's lightweight and impact on the cargo capacity and hence economic viability, Dedes et al.[22]. With battery installations, another key aspect is preventing thermal incidents in battery spaces by ensuring independent ventilation, cooling, and fire extinguishing measures.

TABLE1.

SHIP PARTICULARS FOR HANDYSIZE BULK CARRIER

\begin{tabular}{ll}
\hline Bulk carrier Class & Handysize \\
\hline Ship size (dwt) & 10,000 \\
Length $(\mathrm{m})$ & 115 \\
Breadth $(\mathrm{m})$ & 19.3 \\
Draught $(\mathrm{m})$ & 10 \\
SMCR power $(\mathrm{kW}) / \mathrm{rpm}$ & $2840 / 152$ \\
\hline
\end{tabular}




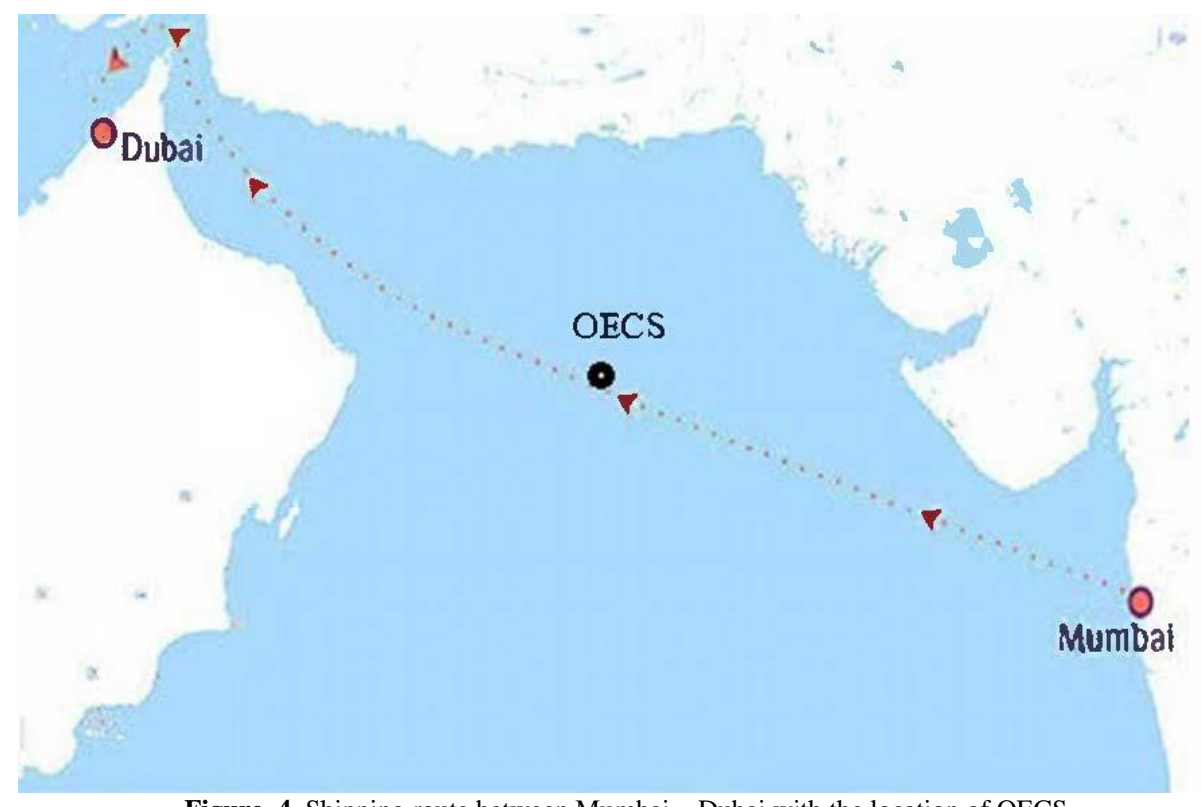

Figure. 4. Shipping route between Mumbai - Dubai with the location of OECS

B. OffshoreElectric Charging Station for the accelerated adoption of electric ships

The availability of adequate charging infrastructure in the sea lanes of the world is one of the key requirements. This will enable faster adoption of electric ships in the maritime industry by ensuring safe, reliable, accessible, and affordable charging infrastructure. The OECS has three main components; a) Floating Solar Plant b) Tension Leg Platform (TLP), and, c) Battery energy storage system.

\section{1) Floating Solar Plant}

The ocean surface utilized to install a Floating Solar Plant (FSP) at sea is a unique source of renewable energy, as it does not use scarce land space. Further, research has shown that a Floating PV system yields $11 \%$ greater outputs than a terrestrial counterpart, Choi [23]. The FSP has PV arrays mounted on a floating platform. PV modules generate direct current (DC) electricity which is stored in BESS through MPPT charge controllers. The floating platform is held in position by installed anchors or self-seating anchors. The power generated by the plant covers $100 \%$ of BESS's total energy demand. Since 2018, several floating solar plants with capacities larger than 250 MW have been installed, Sivakumar [24].

TABLE 2.

FREE VOLUME FOR HANDYSIZE BULK CARRIER

\begin{tabular}{lc}
\hline Ship type & Handysize \\
\hline & 3800 \\
Engine room volume (cu m) & 1300 \\
Free vol in current engine room (cu m) & 1040 \\
Added volume due to electrical components (cu m) & 438 \\
Additional vol due to transformer and motor (cu m) & 436 \\
Deduction for 2-stroke engine removal (cu m) & 96 \\
Deduct for Aux generator romaval (cu m) & 792 \\
Volume available for battery (cu m) & 737 \\
Volume occupied by batteries (cu m) & \\
\hline
\end{tabular}

\section{2) Tension Leg Platform}

While on-shore charging stations are located on land from which to operate, at sea, an artificial platform must be constructed. The TLP acts as a support base for BESS and auxiliaries such as transformers, control rooms, charging stations, etc. The TLP is a platform having tensioned anchoring lines anchored to the sea-bed, see Fig. 3. It was developed for the off-shore oil and gas industry. It has many operational advantages of the fixed platform, whilst reducing the cost of production in water depths up to about $1500 \mathrm{~m}$, Sadeghi et al. [16]. For greater water depths, the concept of a TLP became the only viable choice, Ghosh et, al[25]. One of the world's tallest structures, the Magnolia TLP oil platform,[26] operates at a depth of $1425 \mathrm{~m}$. 


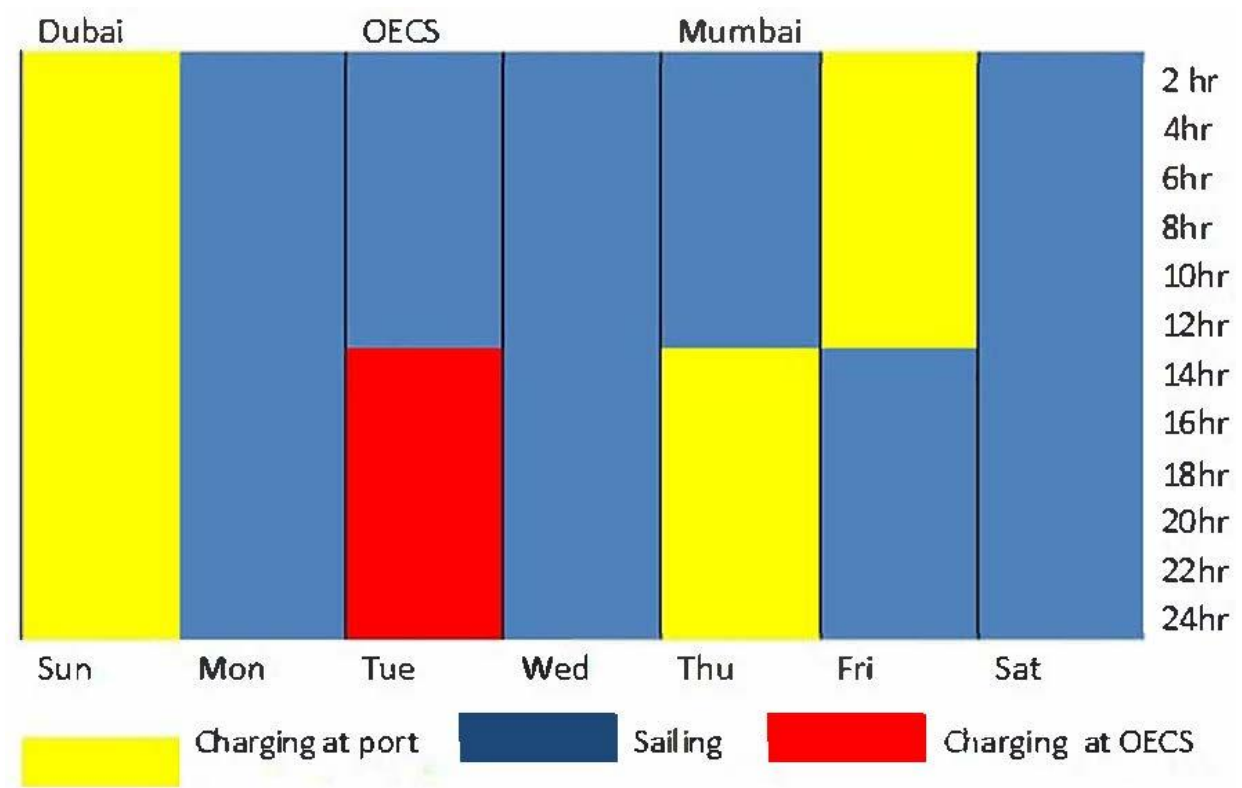

Figure. 5. Typical weekly travel time of AES

\section{BESS}

A battery energy storage system is used to store solar energy generated by the PV plant, and then re-charge the batteries on AES. Lithium-ion (Li-ion) batteries have been considered for the new BESS installations. They have been the preferred choice, thanks to their significant cost declines, favorable performance characteristics, and high energy density, Battery energy report [27]. RollsRoyce [28], has introduced a new battery system specifically designed for ships. More recently, TESLA
[17] has developed a new battery product, called the Megapack, made specifically for utility-scale projects. These large-scale battery installations would require power electronics and a battery management system (BMS). Power electronics control the battery charge whereas the power limits for charging and discharging to the power electronics are provided by the BMS.MAN Energy Solutions [29].

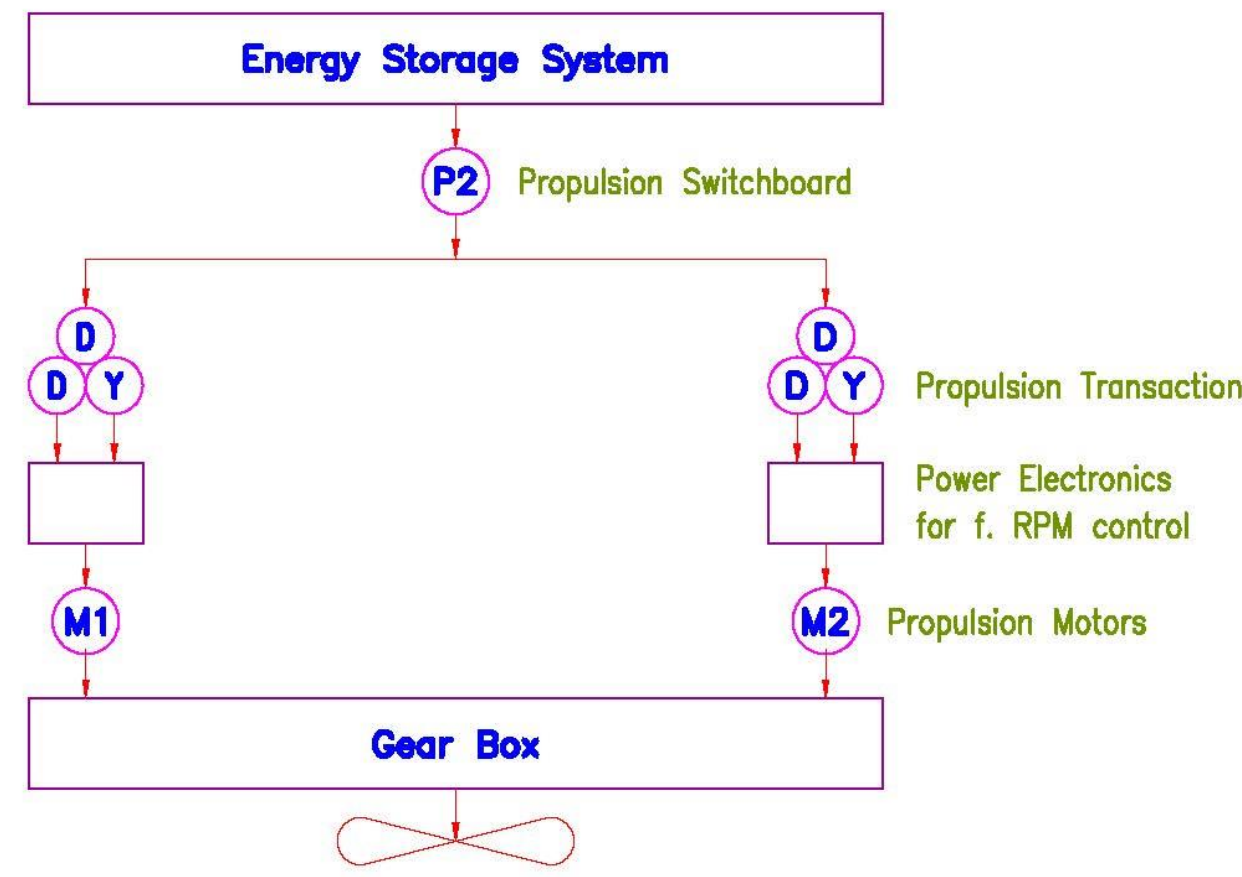

Figure. 6. Concept layout of major components of AES

\section{Problem description}

Made as a practical design application, is a case study of an all-electric cargo vessel (AES) for a typical navigation route from Mumbai to Dubai with a one-stop mid-way for battery recharging. The distance of the shipping route between these two ports is approximately $1941 \mathrm{~km}$, RD World Atlas [30], and the OECS is located mid-way $\left(22^{\circ} .16 \mathrm{~N}, 64^{\circ} .30 \mathrm{E}\right)$ at about $970 \mathrm{~km}$ from either port, see Fig. 4. The average depth at the proposed location is about $200 \mathrm{~m}-500 \mathrm{~m}$. Sizing of an all-electric ship propulsion system is performed and energy consumption results are demonstrated using HOMER software A suitable off-shore battery charging station is designed, comprising of; a) floating solar plant, FSP; b) tension 
leg platform, TLP; and c) a battery energy storage system BESS located on the TLP. Finally, the net present costs (NPC), operational cost, fuel consumption, emissions, etc. of a conventional diesel vessel is assessed and its results are compared with that of the AES.

TABLE 3.

ADDED WEIGHT TO THE SHIP

\begin{tabular}{lc}
\hline Ship type & Handysize \\
\hline Added weight of batteries (mt) & 690 \\
Added weight of propulsion system (mt) & 60 \\
Deduction for 2- stroke engine removal (mt) & 197 \\
Deduct for Aux generator, transformers & 125 \\
and other (mt) & 290 \\
Deduct for fuel oil (mt) & 670 \\
Net deduction (mt) & 80 \\
Final weight added to the vessel & 0.9 \\
(propulsion + storage) $(\mathrm{mt})$ & \\
Increase in lightweight $(\%)$ &
\end{tabular}

\section{E. Preliminary system description}

Fig. 2 gives the configuration of the proposed system. To make a comparison, a ship whose diesel propulsion system is to be converted into a battery-powered propulsion system is selected as the target ship. The target ship (AES) can be classified as a Handysize bulk carrier of 10,000 dwt. Its main characteristic is listed in Table 1, MAN Propulsion trends [31]. The navigation from Mumbai to Dubai takes about 5 days regardless of whether it is from Mumbai-Dubai or in the reverse direction. The period comprises of 24 hours halt each in Mumbai and Dubai for loading/ unloading and charging. The average berthing time for dry bulk carriers is about 26.5 hours. Berthing Policy[32]. A 12-hour halt at the OECS for recharging batteries and $36 \mathrm{hr}$ travel time between port and OECS,(approximate distance 970.5 $\mathrm{km}$ ), for a total of 72 hours travel time per week, see Fig.
5. Consequentially the optimization involves $5616 \mathrm{~h}$ in a year.

\section{F. All-Electric Ship}

The target ship is a 10,000 dwt dry bulk carrier having an electric propulsion system (EPS), which uses electric power stored in a battery. It consists of a BESS, a power converter, a motor, and a propeller, see Fig.6.

1) Loading

The normal continuous rating (NCR), at which ships operate is $85 \%-90 \%$ of the maximum continuous rating, (MCR), Koumentakos A.G. [14]. Thus, $75 \%$ to $77 \%$ of MCR. is the usual output at which ships operate.Then, $75 \%$ of $\operatorname{SMCR}($ as indicated in Table 1$)=0.75 \times 2840=$ $2130 \mathrm{~kW}$.

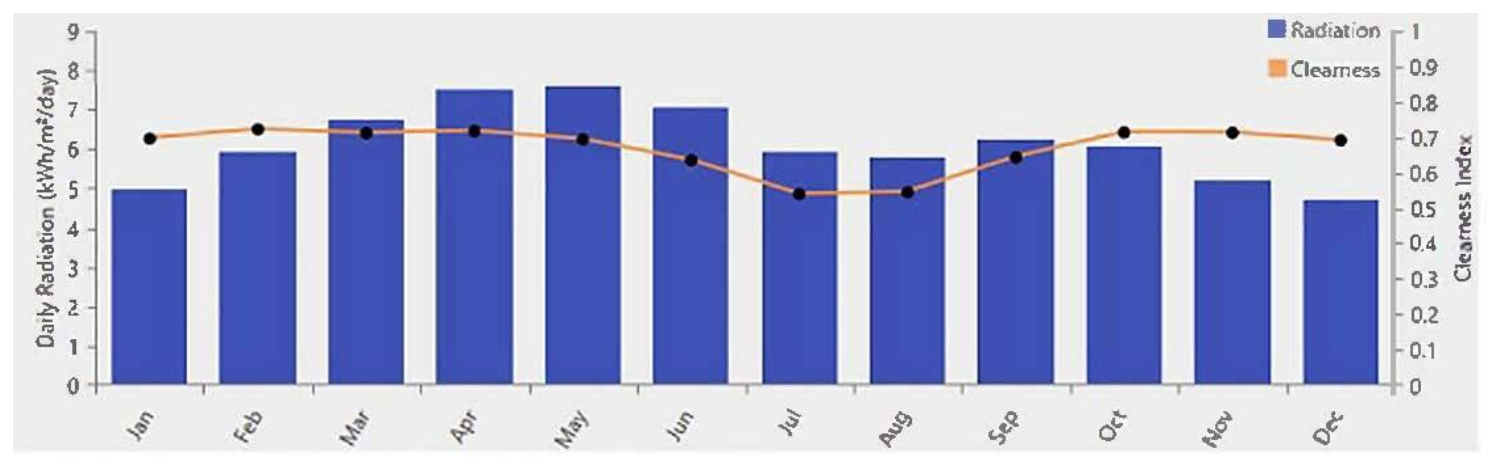

Figure. 7. Solar data at the location of OECS

Allowing $13 \%$ power loss due to efficiency of the motor, $=376 \mathrm{~kW}$

Then, net power required $\mathrm{P}=2130+376=2506 \mathrm{~kW}$ It is assumed that the propulsion energy requirement of the AES will partly be met by PV during daylight hours and balanced by BESS.

For a 36 hours trip T, from port to OECS, or OECS to port, the energy requirement $\mathrm{E}$, will be:

$\mathrm{E}=\mathrm{P} \times \mathrm{T}$
It is to be noted that ship power is a function of speed. For a typical 50,000 dwt vessel, the propulsion power required for sailing $5 \mathrm{~nm}, 12 \mathrm{~nm}$, and $200 \mathrm{~nm}$ out of the port is $314 \mathrm{kWh}, 2.2 \mathrm{MWh}$, and $77 \mathrm{MWh}$ respectively.MAN Propulsion trends [31]. However, for simplification, the present design assumes that the ship travels at cruising speed from port to OECSat full power of $2500 \mathrm{~kW}$. For AES the Li-ion battery energy requirement $\mathrm{Eb}$ will be $\mathrm{Eb}=60 \mathrm{MWh} /$ day and a peak load of $2.5 \mathrm{MW}$ DC. The typical load diagram is shown in Fig.8

$E=2500 \times 36=90,000 \mathrm{kWh}$, or $60,000 \mathrm{kWh} /$ day. 


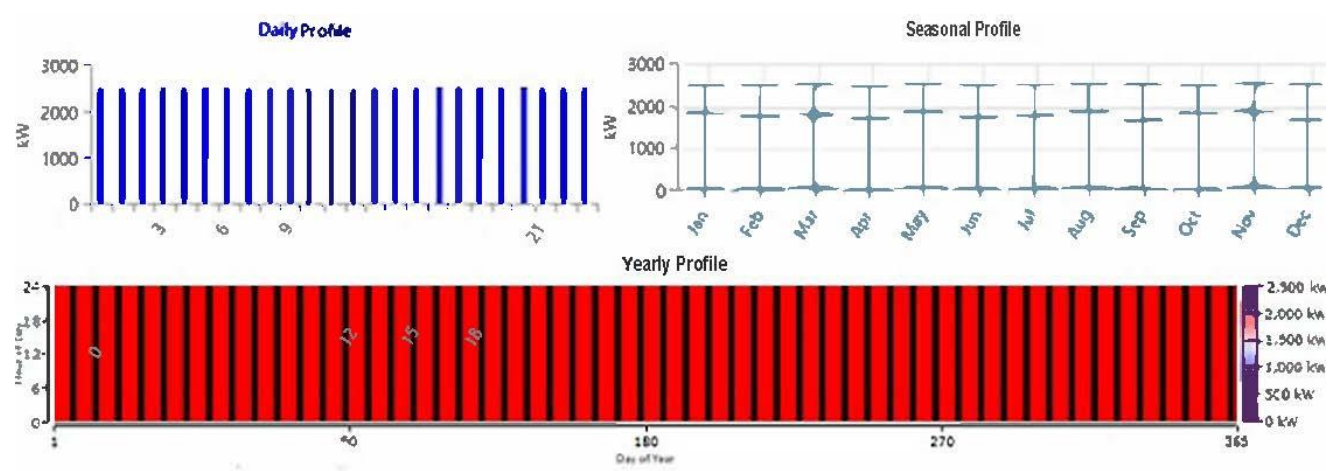

Fig.8 Load diagram for AES

Figure. 8. Load diagram for AES

To meet this demand, the ship will use 30 individual MegaPacks each of $3 \mathrm{MWh}$ capacity. These batteries require $40 \%$ less space and have a higher density than current systems, Tesla Mega Pack [17]. To charge these batteries, Homer software has calculated that $72 \mathrm{MWh}$ capacity batteries are required to be installed on the charging station. At OECS, the AES is charged from PV/BESS, whereas at port they would be charged from the

local grid. As no loading or unloading is carried out at the OECS during the $12 \mathrm{~h}$ halt, the electrical needs are moderate Melode G.[33], and can be met by the reserve energy in BESS. However, a $300 \mathrm{~kW}$ diesel generator is provided to cater to any emergency loads.

\section{2) Space requirement}

The space requirement of the battery system and components need to be assessed so as not to increase the size of the engine room or encroach on the area reserved for cargo. The volume occupied by BESS $=30 \times 7.09 \times 1$, $59 \times 2.18 \mathrm{~m}=737.26 \mathrm{cum}$. Then, net free space available in engine room based on data indicated by Dedeset,al[22], is as per Table $2=3800-(1478+737)$ $=1585 \mathrm{cu} \mathrm{m}$. To further reduce the footprint, packs can be double stacked, increasing the height of the battery bank from $2.18 \mathrm{~m}$ to $4.38 \mathrm{~m}$. Thus, the engine room volume is not exceeded, making it suitable for installation.

3) Weight restriction

Apart from volume, weight calculations and distribution are equally important. The added weight due to propulsion system retrofitting also has to account for the added mass of the energy storage medium. Using data from Dedes et al.[22], and the weight value of Mega Pack as 23 t/pack,(Roszell T. [34], the added weight of batteries $=30 \times 23=690 \mathrm{t}$., and for motor, transformer, and converter 60t.The deductions as shown in Table $3=$ $670 \mathrm{t}$. Hence,there is a net addition in weight of $(750-$ $670)=80$ t. This is about $0.9 \%$ of ship lightweight, and the extra weight may be subtracted from the ballast water, as added lightweight reduces this amount instead of cargo capacity, Dedes et al[22].

\section{G. Offshore electric charging station}

\section{1) Floating solar PV plant}

Solar resources data for the proposed location of the OECS is obtained from NASA, [35]. By entering the latitude and longitude for the proposed location $\left(22^{\circ} .16\right.$ $\mathrm{N}, 64^{\circ} .30 \mathrm{E}$ ), the solar resource shown in Fig.7 is generated. From this, the scaled annual average solar irradiation is $6.15 \mathrm{kWh} / \mathrm{m}^{2} /$ day. This is taken as representative of the proposed location of the OECS and is used in HOMER software. The plant is required to supply $60,000 \mathrm{kWh} /$ day of energy to charge BESS on the AES. The specifications of the PV data used are shown in Table 4. A pontoon-based floating structure is used to mount the PV panels.Ceil\& Terre Int [36], is one firm that specializes in providing such a system. Homer optimization results indicate a PV plant capacity of 60 MW. Using 340W solar panels, the number of PV panels required is 176,470 . Generally, a standard ratio between the PV module area and the required surface area is taken as 3, thus, the installation area required is about $318,900 \mathrm{~m}^{2}$. The cost of a floating solar plant is taken as $\$ 0.9 / \mathrm{W}$, SERI, [15]. 


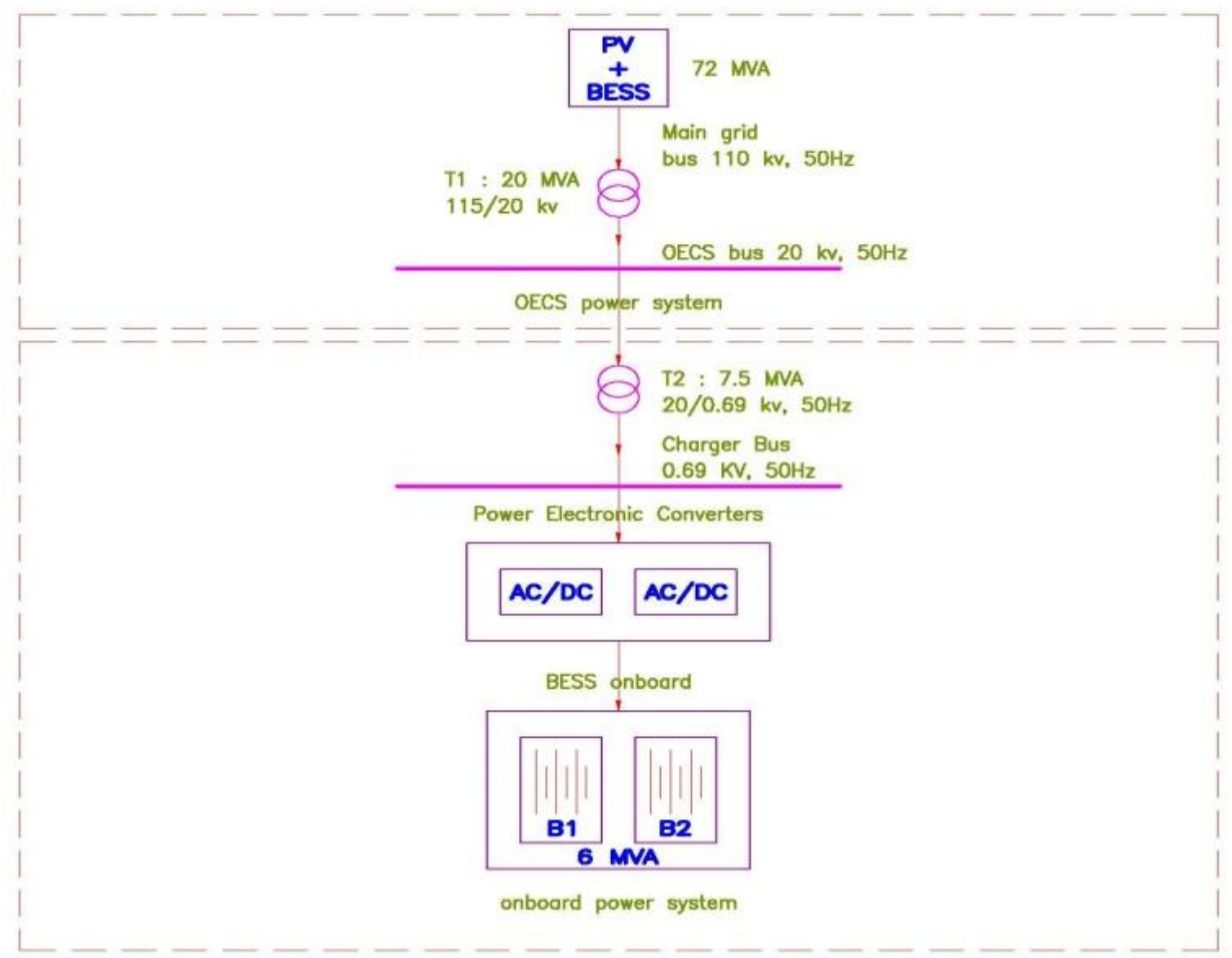

Figure. 9. Schematic showing slow charging of onboard batteries

\section{2) Tension Leg Platform}

A TLP was chosen for this deep water application because of its many advantages, such as a) simple and economical structure, b) less offshore work; c) strong mobility, and d) applicable to deepwater fields. A general overview of design, construction, load-out, transportation, and installation of offshore platforms is covered by Sadeghi, [16]. The selected TLPwith the trade name Pela Star TLPis based on the design for a 6 MW wind turbine, Hurley\& Nordstrom, [37]. The structure is found at a depth of about $200 \mathrm{~m}$ and features two levels of structural steel decks of size $25 \mathrm{~m}$ x $25 \mathrm{~m}$. Though the baseline design is for $130 \mathrm{~m}$ depth of water, Fang\& Duan, [38] have shown that TLP is not sensitive to the depth of water. The main design components are given in Table 5. Cost break-up is shown in Table 7.
The cost is adjusted to allow for the increased length of tendons.

The deck structure is made of steel. The 24 units of BESS are located on the lower deck, which is positioned about $15 \mathrm{~m}$ above mean sea level the upper deck is meant for sub-station, charging device, accommodation, etc. An extension is provided for helideck to allow for use of helicopters for crew transfer.

The total floor area is $2 \times 625=1250 \mathrm{~m}^{2}$.

Each container size unit of Mega Pack weighs 23 t. Total weight of 24 units $=582 \mathrm{t}$. Live load for deck design $=$ $582 / 625=0.89 \mathrm{t} / \mathrm{m}^{2}$

TABLE 4.

PV DATASHEET

\begin{tabular}{cc}
\hline Cell type & Mono-crystalline \\
\hline PV panel rated power (W) & 340 \\
Operating voltage (V) & 33.9 \\
Operating current (A) & 9.89 \\
Open circuit voltage (V) & 41.2 \\
Short circuit current (A) & 10.39 \\
Module efficiency & $20.16 \%$ \\
Dimension lxbxh (mm) & $1675 \times 992 \times 35$ \\
Weight $(\mathrm{kg})$ & 18.5 \\
\hline
\end{tabular}

Structural steel weight

@ $1.2 \mathrm{t} / \mathrm{m}^{2} \times 1250=1,500 \mathrm{t}$
Structural steel cost from Maness, et, al, [39]. 


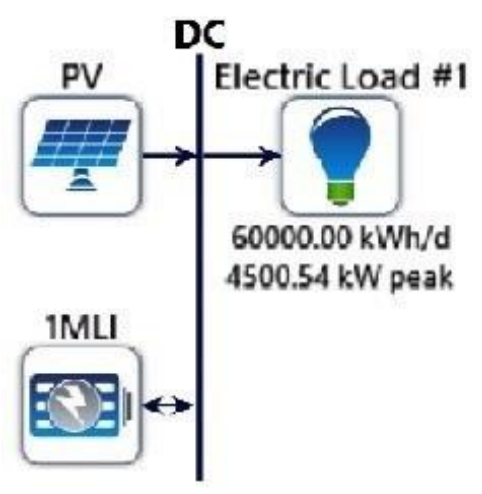

Case 1

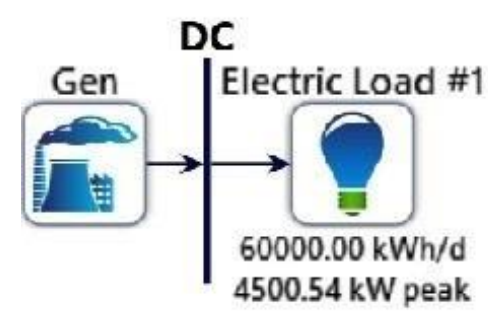

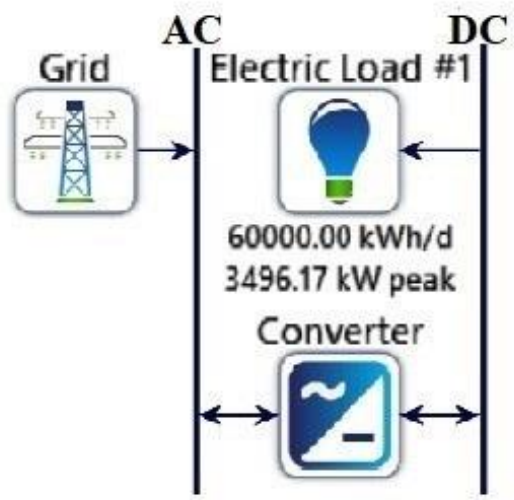

Case 2

Cost;

\section{Case 3}

Figure. 10. Schematic system architecture for cases 1, 2, \& 3

\$000 Struc Platform Fabrication cost, 1500 t @

\section{$\$ 14,500 / \mathrm{t}$}

Switch gear

$$
=21,750
$$$$
=500
$$$$
=2,000
$$

Accommodation, fire, etc

$=24,250$

$=11,590$

TLP (see Table 3)

Charging device, a lump sum amount

Design

Contingencies
$=5,000$

$=5,000$

$=4,160$
Then, total costs of structural platform, TLP, Charging device, design, and contingencies,

$=(11.59+24.25+5+5+4.16) \times 10^{6}=\$ 50 \times 10^{6}$

Because the costs associated with the TLP are unlike any other component for inputs to HOMER, these costs are included in the system design for BESS.

TABLE 5.

PARTICULARS OF PELA STAR HULL

\begin{tabular}{lc}
\hline Lower hull depth (m) & 8.75 \\
\hline Lower Hull dia (m) & 17.0 \\
Column length below LAT (m) & 12.3 \\
Draught LAT (m) & 21.05 \\
Arm eff. Radius ( m) & 31.2 \\
Arm root width (m) & 3.5 \\
Arm tip width (m) & 3.0 \\
Primary steel weight $\quad(\mathrm{m} \mathrm{t})$ & 1500 \\
Displaced volume (cu m) & 4723 \\
Anchor piles Dia (m) \& length (m) & $4.0 \& 25-50$ \\
\hline
\end{tabular}

3) Battery energy storage system

To store the energy from the PV plant, Homer has calculated thata72 an MWh battery system is required. To store this energy, TESLA's massive new energy product Mega Pack battery is selected (Tesla). Each Mega-Pack has a capacity of $3 \mathrm{MWh}$.However, for the Homer optimization input, a generic $1 \mathrm{MWh}$ Li-ion battery is considered, technical parameters of which are given in Table 6. Then,the total number of Mega Pack batteries required $=72 / 3=24$

(4)
The length and width of the battery are $7.1 \mathrm{~m}$ and 1.6 $\mathrm{m}$ respectively. For costing, an assumed installed storage of $70,000 \mathrm{kWh}$ BESS is taken, in addition to the $\$ 50 \mathrm{~m}$ costs of TLP, etc.

The base price ofthe battery from Battery Storage [27] = $\$ 160 / \mathrm{kWh}$ Adding the cost of Structural platform, TLP, etc $=50 \times 106 / 70=\$ 714 / \mathrm{kWh}$

Then, installed cost of BESS $=\$ 874 / \mathrm{kWh}$

This value is taken as the input cost when calculating the $\mathrm{NPC}$, etc. for BESS. 
TABLE 6.

BATTERY DATASHEET

\begin{tabular}{ll} 
& BATTERY DATASHEET \\
\hline Battery type & Li-ion \\
\hline Battery voltage $(\mathrm{V})$ & 600 \\
Nominal capacity $(\mathrm{kWh})$ & $1000+03$ \\
Nominal capacity $(\mathrm{Ah})$ & $1.67 \times 1000+03$ \\
Nominal charge current $(\mathrm{A})$ & $1.67 \times 1000$ \\
Nominal discharge current $(\mathrm{A})$ & $5 \times 1000$ \\
\hline
\end{tabular}

4) Battery Chargers: Battery charging can be done in the fast mode which takes about an hour, or in the slow mode which usually takes $8 \mathrm{~h}$ or more. The constant current-constant voltage $(\mathrm{CC} / \mathrm{CV})$ charging is considered the most recommended charging method for both $\mathrm{Li}$-ion and lead-acid batteries, Dearborn S., [40]. In the present scenario, a stoppage-time of $12 \mathrm{~h}$ is assumed at the
OECS, hence slow charging is feasible. The 30 no. $3 \mathrm{MWh}$ each battery on the AES are connected in series to form groups of two. The configuration in Fig. 9.shows a typical arrangement of two batteries each of $3 \mathrm{MWh}$ capacity located on the ship. A step-down transformer steps down the $20 \mathrm{kV}$ OECS bus supply power to the $0.69 \mathrm{kV}$ charger bus.

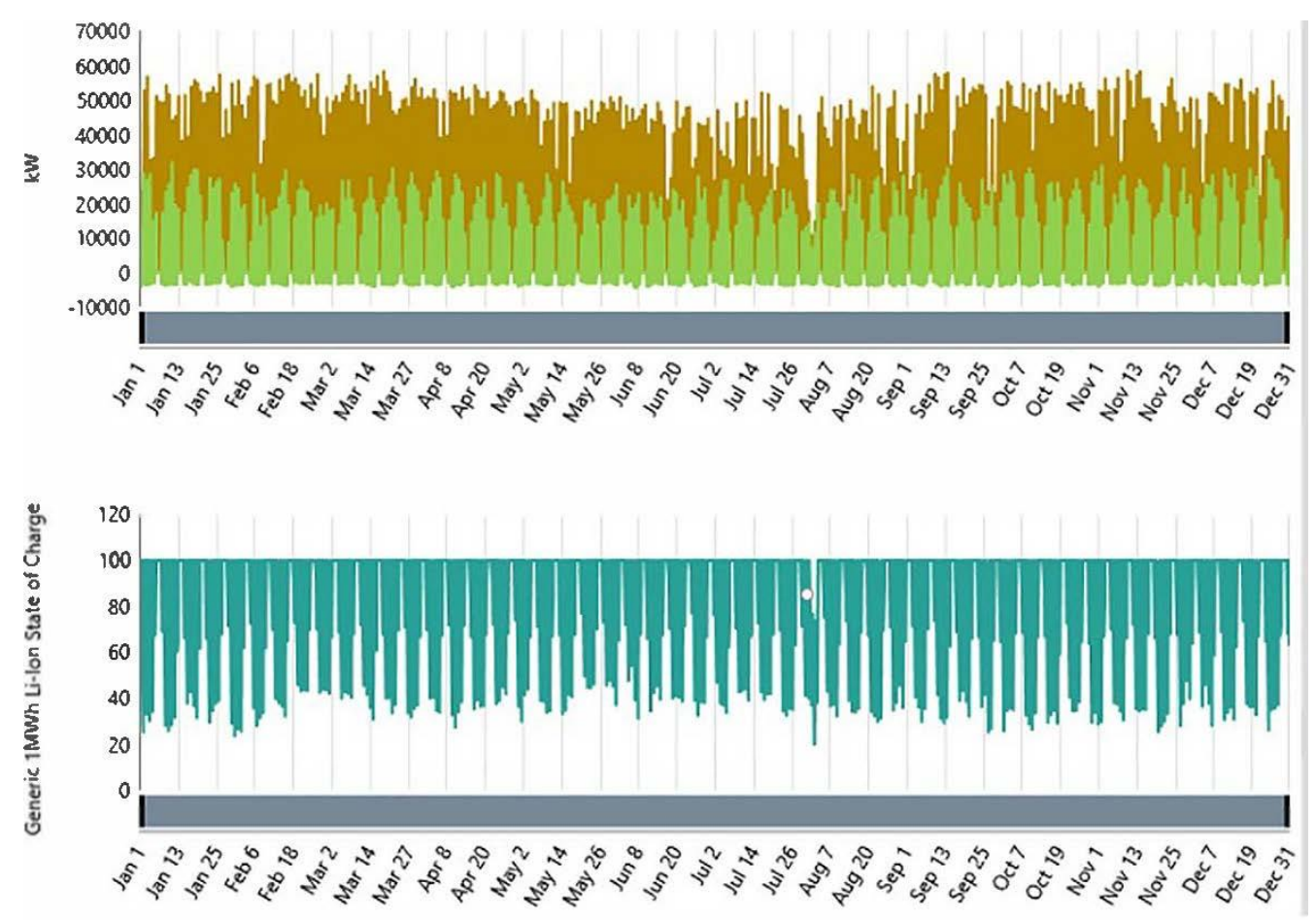

Figure. 11. PV power output; Li-Ion input power; Li-Ion state of charge

The conversion of 0.69 AC to 0.69 DC on board for charging the batteries is done with the help of Power electronic converters. Each battery is charged with a constant current of $0.16 \mathrm{C}$ for $6 \mathrm{~h}$ for slow charging, and this rate provides a constant current of 267 A DC, creating a rise in voltage that depends on the SOC.

TABLE 7.

COST BREAKUP OF PELA STAR HULL

\begin{tabular}{lll} 
& \multicolumn{2}{c}{ COST BREAKUP OF PELA STAR HULL } \\
\hline Item No. & Description & US Dollars \\
\hline 1.0 & Hull Fabrication and Delivery & $\$ 6,289,000$ \\
2.0 & Anchor and Tendon System & $\$ 4,396,000$ \\
3.0 & Installation & $\$ 906,000$ \\
4.0 & Total & $\$ 11,591,000$ \\
\hline
\end{tabular}

Kumar, et al [41] have shown that in simulation studies for a similar arrangement, the batteries are charged within the time frame of $10 \mathrm{~h}$. To cover the cruising range of $970 \mathrm{~km}$, the minimum energy consumption is 90 MWh. 

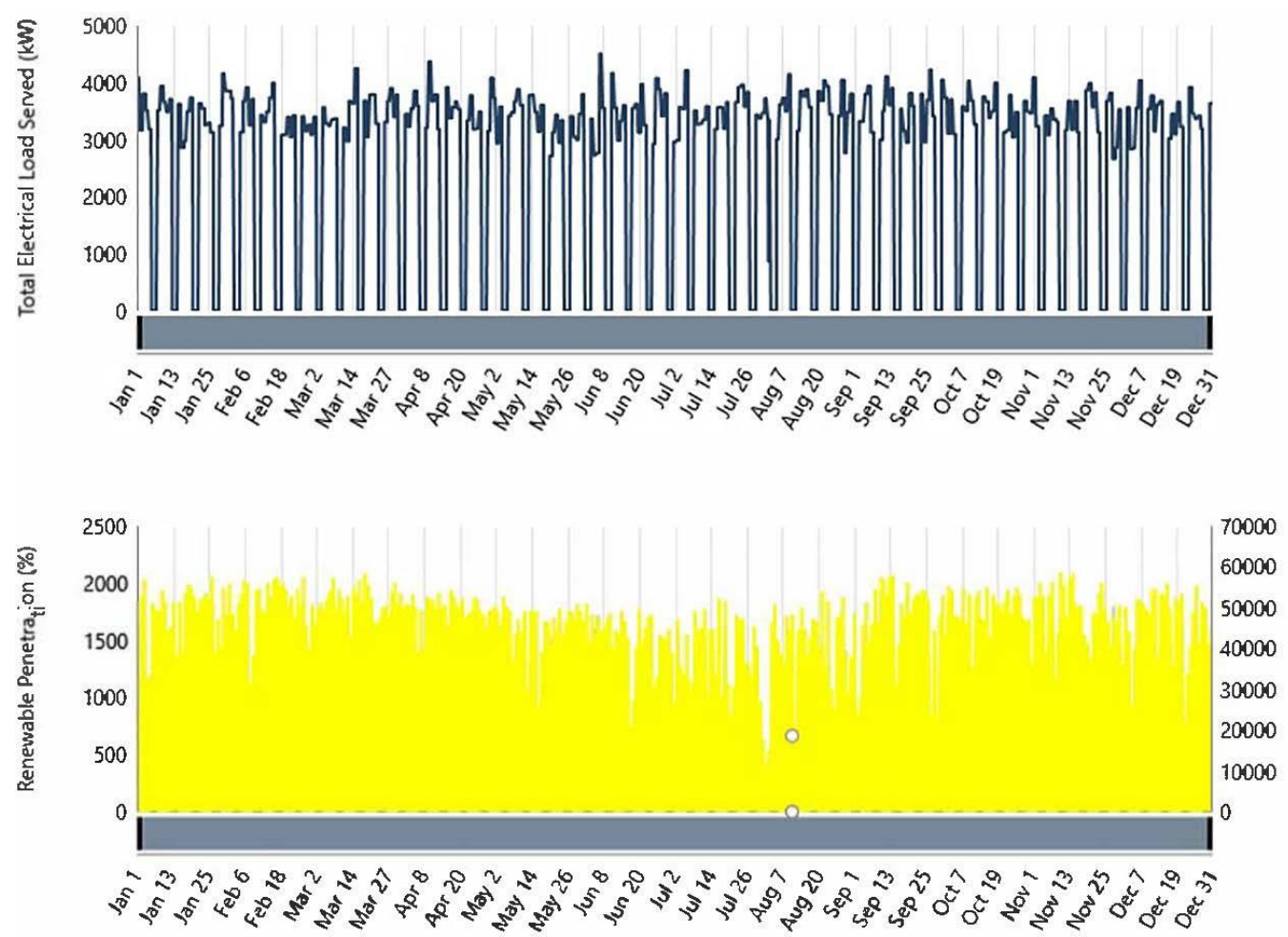

Figure. 12. Electric load served and renewable penetration

Crossing power $(\mathrm{Pc})$ required $=$ Crossing

energy/charging time

Then $\mathrm{Pc}=90 / 10=9 \mathrm{MW}$

This can be supported by the PV/ BESS power system at OECS.

To connect the ship to the OECS power system, a manual connection is envisaged. Automated shore power connection is still an emerging technology, Glosten, [42].

\section{H. Conventional diesel ship}

To assess the benefits of the present technology, the AES is compared with a conventional diesel ship for the same load conditions. The selected ship is a 10,000 dwt Handy Size Bulk carrier navigating between Mumbai and Dubai. Total travel time assumed based on a $27 \mathrm{~h}$ halt at ports and no halt at the OECS is $5616 \mathrm{~h}$ per year. It is designed for an electric load of $60,000 \mathrm{kWh} /$ day, and a $4500 \mathrm{~kW}$ peak. Homer software was used to obtain an optimized generator set and other parameters such as NPC, fuel consumption, and emissions. For a mean electric output of $3253 \mathrm{~kW}$, a $5000 \mathrm{~kW}$ generator is suggested.

\section{RESULTS AND DISCUSSION}

This section discusses the various power and propulsion architecture and their benefits. To solve the multiobjective optimization problems in this paper, Homer software is used. The impact of the integration of an OECS on a ship's power system, load condition, emissions, fuel consumption, and energy storage system are studied to demonstrate the viability of the proposed technology.

TABLE 8.

INPUT DATA REGARDING SYSTEM COMPONENTS

\begin{tabular}{lllll}
\hline System component & Capital cost $(\$ / \mathrm{kW})$ & $\begin{array}{l}\text { Replacement cost } \\
(\$ / \mathrm{kW})\end{array}$ & $\begin{array}{l}\text { O \& M cost } \\
(\$ / \mathrm{kW} / \mathrm{Yr})\end{array}$ & Lifetime Years \\
\hline PV array & 900 & 0.0 & 10 & 25 \\
Li ion BESS & 874 & 160 & 5 & 15 \\
Converter & 300 & 300 & 10 & 5 \\
Diesel generator & 500 & 500 & 0.03 & 20 \\
\hline
\end{tabular}

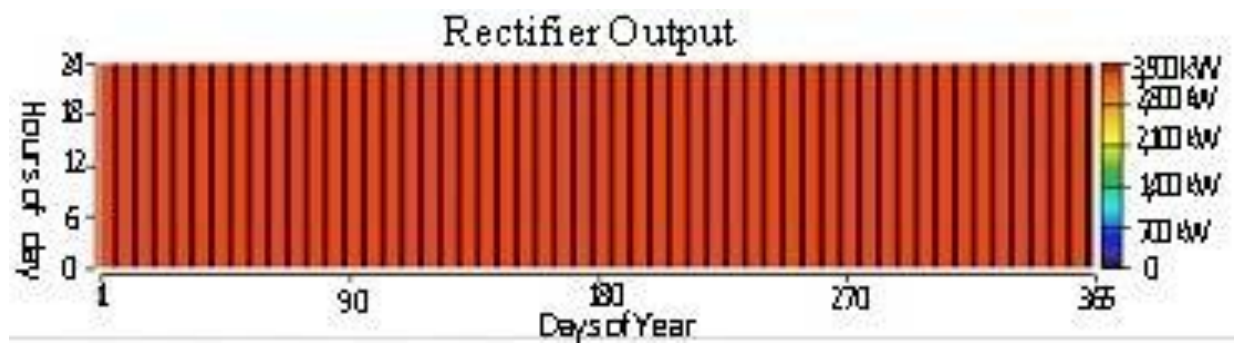

Figure. 13. Rectifier Output for AES 
The following three cases are considered: Case 1 An optimal study of OECS (PV, BESS), considering cost, and energy production.

Case 2 An optimal study of AES (Grid, Converter) considering cost, and energy production.

Case 3 An optimal study of a diesel ship (Generator) considering cost, energy production, fuel consumption, and emissions. The typical system architecture for the three cases is shown in Fig. 10.

\section{A. Economic assessment}

Based on the input cost data indicated in Table 8, the energy balance calculation for each feasible system configuration is performed by Homerto arrive at the COE and NPC. A discount rate of $6 \%$ has been considered for the calculations. The categorized optimal system which has the least COE and NPC is shown in Table 9.

1) Cost of energy
The Levelized Cost of Energy (COE) is the average cost per $\mathrm{kWh}$ of the useful energy produced by the power system, and is given by the following equation;

$\mathrm{COE}=\mathrm{C}_{\mathrm{an}} / \mathrm{E}_{1}$

where $C_{a n}$ is the total annualized cost of the system (\$/yr) and $E_{1}$ is the electric load served. (kWh/yr). Based on Table 9, it can be seen that the optimum COE of the hybrid system $(\mathrm{PV} / \mathrm{B})$, which represents the OECS is $\$ 0.39 / \mathrm{kWh}$. This is slightly higher than the COEof $€$ $0.339 / \mathrm{kWh}(\$ 0.366 / \mathrm{kWh})$ for a combined PV plant with storage Pawel I.,[43] and can be attributed to integrating the high installation cost of TLP. As the sea surface provides unlimited space for locating PV panels, the power system has no restriction on the PV system capacity, allowing for an optimum size that gives the least COE. The optimal system for Case 1 consists of 60 MW of PV systems and 72 MWh of Li-ion Batteries. For AES (Case 2), the optimal size consists of the grid and $3852 \mathrm{~kW}$ of a power converter.

TABLE 9.

CATEGORISED OPTIMISATION RESULTS FOR CASES 1,2, \& 3

\begin{tabular}{llll}
\hline Description & Case 1 & Case 2 & Case 3 \\
\hline PV size $(\mathrm{kW})$ & 60,000 & 0 & 0 \\
BESS cap $(\mathrm{kWh})$ & 72,000 & 90,000 & 0 \\
Converter $(\mathrm{kW})$ & 0 & 3,852 & 0 \\
Grid $(\mathrm{PV}+\mathrm{Bat})(\mathrm{kW})$ & 0 & 999,999 & 0 \\
Generator $(\mathrm{kW})$ & 0 & 0 & 5,000 \\
Total NPC $(\$)$ & $137 \mathrm{M}$ & $99.3 \mathrm{M}$ & $121 \mathrm{M}$ \\
LCOE $(\$ / \mathrm{kWh})$ & 0.3974 & 0.11 & 0.35 \\
Total output & $116,009,503$ & $21,900,000$ & $21,900,000$ \\
KWh/yr) & & & \\
Fuel cost $(\$)$ & 0 & 0 & $5.63 \mathrm{M}$ \\
Total fuel $(\mathrm{L})$ & 0 & 0 & 5,627293 \\
Emissions $(\mathrm{kg})$ & 0 & 0 & $14,730,085$
\end{tabular}

It is to be noted that in this case, power from the grid refers to the power from the PV/ BESS system located on OECS. For Diesel ship (Case 3) the optimal size consists of a $5000 \mathrm{~kW}$ generator. On comparing the COE of the two ships, it can be observed that the COE of the AES (G/C) $\$ 0.11 / \mathrm{kWh}$ is lower than in the case of the diesel ship $(\$ 0.35 / \mathrm{kWh})$. This is attributed to the AES using renewable power supplied by BESS, as opposed to the cost of fuel for the diesel ship and there being no renewable source in the system.

TABLE 10.

NET PRESENT COST'S

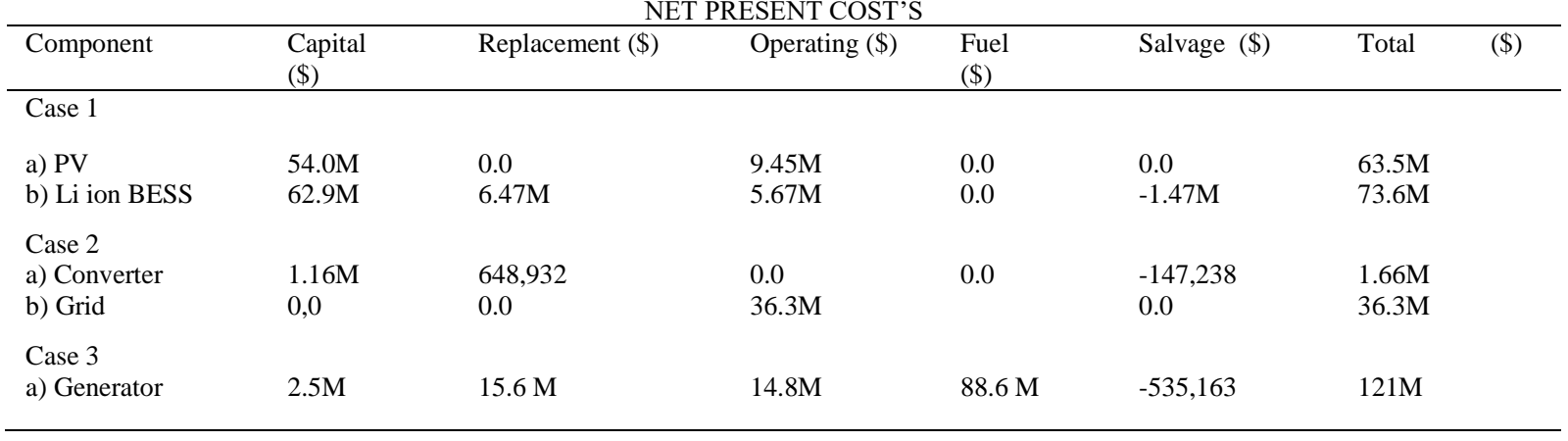

\section{2) Net Present Cost}

The total net present cost (NPC) of a system is the present value of all the costs the system incurs over its lifetime, minus the present value of all the revenue it earns over its lifetime. (25years). Table 9 previews the best-performing system architectures and their costs.
Case1 yields a total net present cost (NPC) equal to $\$ 137$ $\mathrm{m}$. The higher NPC is due to the oversized PV arrays and batteries required for ensuring that the load is fully met. On comparing the NPC of the two ships, Cases $1 \& 2$, it is clear that the NPC of the diesel $\operatorname{ship}(\mathrm{G}) \$ 121 \mathrm{~m}$ is higher than of the NPC of the AES ( $\mathrm{Gr} / / \mathrm{C}), \$ 99.3$ 
$\mathrm{m}$ (after adjusting to include the cost of batteries) and this is due to the amount of fuel required. This leads us to the conclusion that a long sea journey with a stop-over for battery charging can dramatically improve the economic performance of the electric ship.

3) Operating Costs

The operating cost of a Component is the cost associated with the operation of maintaining the component. The operating cost for Case1(PV/B) is \$ 960, 000, see Table 10 . The operating cost for the AES is $\$ 2.31 \mathrm{M}$, and this represents the annual cost of buying power from the PV/ BESS system. For the Diesel ship, the operating cost is $\$ 939,600$, and the cost of diesel fuel required annually is $\$ 5.63 \mathrm{~m}$. This once again highlights the superiority of the AES as against the Diesel ship.

TABLE 11.

POTENTIAL EMISSION SAVINGS DUE TO OECS

\begin{tabular}{lc} 
Emissions & $\mathrm{Kg} /$ year \\
\hline $\mathrm{CO} 2$ & $19,822,942$ \\
Carbon Mono- oxide & 124,953 \\
Unburnt hydro carbons & 5,452 \\
Particulate matter & 757 \\
Sulphur dioxide & 48,542 \\
Nitrogen oxide & 117,380 \\
\hline
\end{tabular}

\section{B. Environmental Assessment}

1) Renewable energy fraction and GHG emissions The fraction of the energy delivered to the load that originated from the renewable power source is termed the renewable energy fraction Homer software calculates the renewable energy fractions and annual emissions and these are indicated in Table 8 . Based on Table, 8 , it can be seen that the systems (PV/B) and $(\mathrm{Gr} / \mathrm{B} / \mathrm{C})$ have the highest renewable energy fractions $(100 \%)$, Fig.11, and no GHG emissions. . For the AES, the optimal mainly depends on PV/BESS for feeding the load demand by the required power, thus resulting in the high, renewable energy fraction. However, for the diesel ship system, the renewable energy fraction is $(0.0 \%)$, and the GHG emission is $20,120,026 \mathrm{~kg} / \mathrm{year}$. The breakup of the different components of emission for the diesel ship is given in Table 11. Hence, it may be concluded that for a given application, a hybrid system design comprised of a PV and BESS charging an AES significantly reduces the carbon emissions. The value addition of an OECS is apparent.

\section{System assessment}

1) PV array

The results obtained in this study are taken for the location of OECS where the average solar irradiance is $6.15 \mathrm{kWh} / \mathrm{m}^{2} / \mathrm{day}$, and the solar resource is available throughout the year. A further advantage of floating solar PV panels is that it allows higher yields (15\% more) due to the cooling effect of water, which could make up for its higher cost, SERI, [15].

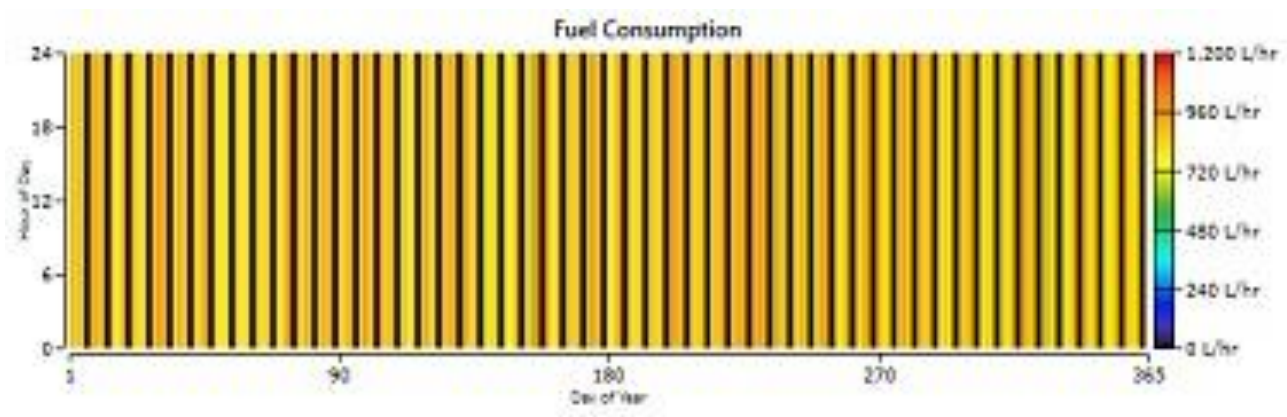

Figure. 14. Fuel consumption for diesel ship

2) Battery energy storage systems There are two BESS considered for this study. The first BESS is located on OECS and is charged by the PV array during daylight hours. Its capacity is determined by the amount of energy required to charge the second BESS, which is located on the AES. Fig 12 shows the state of charge for Case1. The SOC of the battery is about $100 \%$ for most of the year. For the BESS located on the AES, the annual energy purchased from the grid (considered as a proxy for the PV/ BESS power system)is $21,900,000 \mathrm{kWh}$, with a peak demand of 3680 $\mathrm{kW}$. HOMER assumes a rate of $\$ 0.115 / \mathrm{kWh}$ resulting in an annual energy charge of \$2.3.m.

\section{3) Power converter}

The power converters have a dual role. One as an inverter to convert DC power to $\mathrm{AC}$ power and as a Rectifier to convert AC power to DC power. The rectifier located on AES, has a capacity of $3852 \mathrm{~kW}$, Fig.13. 


\section{4) Diesel generator}

Fuel consumption and emissions are key factors governing a diesel ship design. Homer calculates the total fuel consumption Ft using the following equation:

$\mathrm{Fs}=\mathrm{Ft} / \mathrm{Eg}$

where Fs is the specific fuel consumed,i.e. the average amount of fuel consumption per $\mathrm{kWh}$ energy it generates, and Egis is the total annual electricity production of the generator $(\mathrm{kWh} / \mathrm{yr})$. As the ship mainly depends on the diesel generator to feed the load demand, the fuel demand is quite high, (5,627,293L/year), Fig. 14. At a conservative rate of $\$ 0.9 / \mathrm{L}$, the total fuel cost from Table 10 is $\$ 5.63 \mathrm{~m}$. Further, the more frequent the diesel generator operates the shorter its lifetime is in years. In this case, the number of starts is 53 and its lifetime is 2.3years. This accounts for the high replacement cost of $5.6 \mathrm{~m}$.

\section{5) Electricity production}

From the yearly electricity production data shown in Table 9, it can be noted that for the (PV/B) system, PV generation is sufficient to charge BESS located on the OECS. The annual production from PV is $116,009,503$ $\mathrm{kWh} / \mathrm{yr}$, the energy input to BESS is $12,579,403 \mathrm{kWh} / \mathrm{yr}$ and its output energy is $11.346,890 \mathrm{kWh} / \mathrm{yr}$. The period of autonomy is $23 \mathrm{~h}$. There is excess electricity of $92,883,147 \mathrm{kWh} / \mathrm{yr}$ from the PV installation, part of which is used for the shortfall from BESS, and balance for the daily electricity demands of facilities located on TLP. For the case of the power system on AES (G/B/C), the ship purchases $23,052,630 \mathrm{kWh} / \mathrm{yr}$ power from the grid (in this case the PV/Bat system of Case 1) and consumes $21,900,000 \mathrm{kWh} / \mathrm{yr}$ to charge the $90 \mathrm{MWh}$ batteries which drive the motor. For the diesel ship $(\mathrm{G})$, we can see that Homer optimization results in a standalone $5000 \mathrm{~kW}$ generator to meet the load demand of 21,900,000 kWh/yr. The conclusion resulting from this work indicates that increased PV capacity and BESSare essential to reduce the fuel consumption and emissions of merchant ships, and the role played by OECS is crucial in this regard.

\section{Suggested Further Research}

A subject of further research related to the present technology but with broader defined system boundaries would be an evaluation of providing offshore electric charging stations for routes typically navigated by the large ocean-going vessels, requiring open sea crossings. A typical crossing between Pontada Madeira, Brazil, and Rotterdam, Europe covers a distance of about $4100 \mathrm{~nm}$ with ultra-deepwater depths of over $3000 \mathrm{~m}$. It is suggested that a floating production, storage, and offloading (FPSO) unit could be employed for such routes. An example is the Turritella FPSO design based on the conversion of an existing Suezmax -scale double hull tanker, and operating in 2,896 m (9500 feet) of water, Blake, [44]. Such a vessel can be retrofitted for storing batteries and related equipment to serve as an offshore electric charging station. The modified OECS could then be co-located with a floating solar farm that produces the necessary electrical energy to charge the batteries. A Belgian company Energy global,[45], is already working on a pilot project for a solar PV project technology that allows solar panels to be installed for high-wave offshore application, with the modules and structures designed to be resistant to saltwater, strong streams, and high waves. In keeping with the decision for a clean energy environment, Green Ports would be developed to charge vessels purely from RES dedicated to the needs of the ports.

\section{CONCLUSION}

This paper presents novel environmental technologies for mitigating carbon emissions at sea, which are mostly generated from onboard diesel consumption. In response to this challenge, the approach taken in this study was the introduction of an OECS on long-distance shipping routes, along with an AES concept. The scope of this study was to assess the technical feasibility of a commercially viable offshore electric ship charging station (OECS), built-in deep waters along commercial shipping routes to facilitate battery charging for AES/hybrid ships. It has been shown that a charging platform to support BESS can be constructed in deep waters, along commercial shipping routes, using TLP technology. PV arrays on a floating solar plant (60 MW) co-located along the TLP provide power for charging BESS (72 MWh). A case study is given of a 10,000 dwt all-electric cargo ship traveling the $1941 \mathrm{~km}$ route between Mumbai and Dubai, with an OECS located midway along the route at which the AES docks recharge its $90 \mathrm{MWh}$ batteries. A comparison is made with a sister ship having diesel propulsion. Simulation with Homer software presented in this study shows that AES has a lower NPC of $\$ 99 \mathrm{M}$ compared to that of the diesel ship $\$ 121 \mathrm{M}$. Further, it is shown that the AES is anticipated to save 5,627,293 1 annually in fuel consumption, and prevent $19,823 \mathrm{t} / \mathrm{yr}$ of $\mathrm{CO}_{2}$ from entering the atmosphere. Another study found that at the present stage of the development of battery technology, the installation of batteries was weight and volume-wise practically feasible for the AES. In conclusion, it can be said that the integration of an OECS along with an allelectric/ hybrid ship concept represents a major milestone in bringing emission-free technology to the marine sector, whilst allowing electric sailing across long distances over a longer period.

\section{REFERENCES}

[1] International Maritime Organization. Third IMO GHG Study 2014 Executive Summary and Final Report; International Maritime Organization: London, UK, 2015. [Google Scholar]

[2] Micco, A.; Perez, N. Maritime Transport Costs and Port E_ciency. In Towards Competitiveness: The Institutional Path; Inter-American Development Bank: Santiago, Chile, 2001

[3] Eyring, V., Isaksen, I. S. A., Berntsen, T., Collins, W. J., Corbett, J. J., Endresen, O., Grainger, R. G., Moldanova, J. Schlager, H. and Stevenson, D. S., Transport Impacts on Atmosphere and Climate. Atmospheric Environment, 44 (37): $4735-4771,2010$

[4] International Chamber of Shipping. Annual Review 2018; International Chamber of Shipping: London, UK, 2018

[5] UNCTAD, 2008. Review of maritime transport. In: Proceedings of the United Nations Conference on Trade and Development, Accra (Ghana). 
[6] Balcombe P, Rigby D, Azapagic A. Environmental impacts of microgeneration: integrating solar PV, Stirling engine CHP and battery storage. Appl Energy 2015;139:245-59. http://dx.doi.org/10.1016/j.apenergy.2014.11.034

[7] Zakeri B, Syri S. Electrical energy storage systems: a comparative life cycle cost analysis. Renew Sustain Energy Rev 2015;42:569-96. http://dx.doi.org 10.1016/j.rser.2014.10.011.

[8] Sakalis, G.N.; Tzortzis, G.J.; Frangopoulos, C.A. Intertemporal Static and Dynamic Optimization of Synthesis, Design, and Operation of Integrated Energy Systems of Ships. Energies 2019, 12, 893. [Google Scholar] [CrossRef]

[9] Fahd Diab, Hai Lan, Salwa Ali Novel comparison study between the hybrid renewable energy systems on land and on ship Renewable and Sustainable Energy Reviews 63 (2016) 452-463

[10] European Commission. The Commission Calls for a Climate Neutral Europe by 2050. Available online: http://europa.eu/rapid/press-release_IP-18--6543_en.htm

[11] Nazir C.P.,'Solar Energy for Traction of High-Speed Rail Transportation: A Techno-economic Analysis, Civil Engineering Journal Vol 5, No.7, July 2019 pp1566-1576 DOI: 10.28991/cej-2019-03091353

[12] "Corvus Energy: CASE STUDY: Norled AS, MF Ampere, Ferry,"

http://files7.webydo.com/42/421998/UploadedFiles/a446557414ff-4689-a033-08ac32adada1.pdf

[13] Quanlin, Q. China Daily. Available online: http://www.chinadaily.com.cn/business/2017--

11/14/content_34511312.htm

[14] Koumentakos A.G.2019 'Developments in Electric and Green Marine Ships' http://www.mdpi.com/journal/asi

[15] Solar Energy Research Institute of Singapore 2019 Floating Solar- Market-Report.pdf

[16] Sadeghi Kabir, Tozan Hudaverditension leg platforms: an overview of planning, design, construction, and installation Academic Research International Vol9 (2) June 2018

[17] Tesla Mega Pack.2020 www.tesla.com/megapack

[18] Homer Pro,

2019:

https://www.homerenergy.com/products/pro/index.html

[19] Optimal sizing of hybrid PV/diesel/battery in ship power system q Hai Lan, Shuli Wen, Ying-Yi Hong, David C. Yu, Lijun Zhang Applied Energy 158 (2015) 26-34

[20] MARPOL. Lloyd's Register Rule finder 2005. Available online: http://www.mar.ist.utl.pt/mventura/Projecto-Navios-I/IMOconventions $\% 20 \% 28$ copies\%29/MARPOL.pdf

[21] Volker T. Hybrid propulsion concepts on ships. In: ZeszytyNaukoweAkademiiMorskiej w Gdyni, vol. 79; 2013. p. 66-76.

[22] E K Dedes, D A Hudson and S R Turnock Technical feasibility of hybrid propulsion systems to reduce exhaust emissions of bulk carriers Trans RINA Vol 154, Part A4, IntJ Maritime Eng, Oct-Dec 2012

[23] Choi Y. Utilization of renewable energy technology in the mining industry. J. Korean Soc Min Energy Resources Eng 2013; 50:422-9

[24] Sivakumar, B. 2019. "Tangedco aims for 250MW solar floating projects." The Economic Times, January 25. economictimes.indiatimes.com/news/renewable/tangedco-aimsfor-250mw-solar-floating-projects/67682064.

[25] Susobhan Ghosh, Frank S. Chou, Edward W. Huang, https://www.cooperative.com/programs-

services/bts/Documents/Reports/Battery-Energy-StorageOverview-Report-Update-April-2019.pdf

[26] Magnolia oil platform https://geology.com/stories/13/magnoliaoil-platform/ 2013

[27] Business \& Technology Report Battery Energy \& Storage Overview Battery-Storage- Overview-Report-Update-April2019.pdf

[28] Rolls-Royce Launches New Battery System for Ships - Energy 2018 ... www.iene.eu , rolls-royce-launches-new-batterysystem-for-ships-p44.

[29] MAN Energy Solutions, batteries -on-board-ocean going vessels.pdf 2019

[30] The Readers Digest World Atlas, Published by Readers Digest Association Ltd. Cambridge Univ. London, 1961

[31] MAN Propulsion-trends-in bulk-carriers.pdf 2019

[32] berthing policy for dry bulk cargo for major ports - Tariff 2016...www.tariffauthority.gov.in > writereaddata > UploadFile > BerthingPo...PDF
[33] G de Melo Resizing study of main and auxiliary engines of the container ...upcommons.upc.edu $>$ bitstream $>$ PDF

[34] Roszell, Tim 2020. "Saint John Energy adding money-saving battery power to its energy grid". Global News.

[35] NASA. Surface Meteorology and Solar Energy. Available online: https://eosweb.larc.nasa.gov/sse/

[36] Ciel \& Terre International, $2011 \mathrm{http} / / / \mathrm{www} . c i e l-e t-t e r r e . n e t /$

[37] William L. Hurley, Jr., Charles J. Nordstrom, 2014 PelaStar Cost of Energy: A cost study of the PelaStar floating foundation system in UK waters File No. 12004.01, Glostenwww,glosten.com

[38] Huacan Fang, Menglan Duan Offshore Operation Facilities: Equipment and Procedures ISBN 978-0-12-396977-4 DO https://doi.org/10.1016/C2011-0-07477-XGulf Professional Publishing

[39] Michael Maness, Benjamin Maples, and Aaron Smith Technical Report NREL/TP-6A20-66874 January 2017http:/www.osti.gov/scitech

[40] Dearborn, S. Charging Li-ion Batteries for Maximum Run Times. Power Electron. Technol. 2005, 40-49

[41] Jagdesh Kumar, Aushiq Ali Memon, Lauri Kumpulainen, Kimmo Omid PlaizbanDesign and Analysis of New Harbour Grid Models to Facilitate Multiple Scenarios of Battery Charging and Onshore Supply for Modern Vessels Energies 2019, 12(12), 2354; https://doi.org/10.3390/en12122354

[42] Glosten, WSF Medium Voltage Shore Power Feasibility Study 20 Hybrid Charging Feasibility Study.pdf 2018

[43] Ilja PawelThe cost of storage - how to calculate the levelized cost of stored energy (LCOE) and applications to renewable energy generation Energy Procedia $46 \quad$ (2014) 68 - 77 www.sciencedirect.com

[44] Blake Moore, Andrew Easton, Jonathan Cabrera, and Carl Webb, Turritella FPSO_Design and Fabrication of the World's Deepest Producing Unit JPT 01 February 2018 Volume: 70 | Issue:2

[45] high-wave offshore solar panels soon a reality.htm www.energyglobal.com/solar/18072019/ 